\title{
BIMBINGAN DENGAN PENDEKATAN EKOLOGI UNTUK MEMAKSIMALKAN PENCAPAIAN TUGAS PERKEMBANGAN ASPEK SOSIAL EMOSIONAL ANAK TAMAN KANAK - KANAK (TK)
}

\author{
Novi Wahyu Hidayati, Martin, Hastiani \\ Program Studi Bimbingan dan Konseling, IKIP PGRI PONTIANAK \\ opinyasuwarno@gmail.com
}

\begin{abstract}
Abstrak
Tujuan dari penelitian ini adalah merancang bimbingan untuk mengoptimalkan pencapaian tugas perkembangan aspek sosial-emosional anak Kelompok A Taman Kanakkanak TK Tunas Harapan Bangsa Kecamatan Sungai Raya Kepulauan Kabupaten Bengkayang, maka metode penelitian yang digunakan dalam penelitian ini adalah metode penelitian deskriptif dengan bentuk penelitian adalah studi kasus (case study).secara keseluruhan hasil observasi menunjukkan bahwa: 1) terdapat sebanyak 11 anak termasuk kategori tingkat ketercapaian tugas-tugas perkembangan "sangat tinggi" dengan persentase mencapai $14,67 \%, 2)$ terdapat sebanyak 55 anak termasuk kategori tingkat ketercapaian tugas-tugas perkembangan "tinggi" dengan persentase mencapai 73,33\%, 3) terdapat sebanyak 9 anak termasuk kategori tingkat ketercapaian tugas-tugas perkembangan "rendah." dengan persentase mencapai $12 \%$, dan 4) tidak terdapat anak yang termasuk kategori tingkat ketercapaian tugas-tugas perkembangan "Sangat Rendah", Rancangan bimbingan dan konseling dengan pendekatan ekologis untuk memaksimalkan tugas perkembangan aspek sosial-emosional dimulai dari perumusan rasional, perumusan visi dan misi, pengertian, deskripsi kebutuhan, perumusan tujuan, rencana operasional (action plan), pengembangan tema atau topik, perumusan program, pengembangan satuan layanan, rencana evaluasi dan rencana anggaran.
\end{abstract}

Kata Kunci: ekologi, sosial emosional, taman kanak-kanak.

ABSTRACT
The purpose of this study is to design a guidance to optimize the achievement of the developmental tasks of social-emotional aspects of child Group A kindergarten kindergarten Tunas Harapan Bangsa Sungai Raya subdistrict Bengkayang Islands, the research method used in this study is the descriptive research method to study shape is case studies (case study). Overall observation results show that: 1) there are as many as 11 children, including category level achievement of developmental tasks "very high" by the percentage reached $14.67 \%$, 2) there are as many as 55 children, including the achievement level categories developmental tasks "high" with the percentage reached $73.33 \%, 3)$ there are as many as 9 children, including the achievement level categories of developmental tasks "low." the percentage reaches $12 \%$, and 4) there are no children who are categorized as level of achievement developmental tasks "Very Low", draft guidance and counseling with an ecological approach to maximize the developmental tasks of social-emotional aspects starting from the rational formulation, formulation of vision and mission, understanding, description of needs, formulation of objectives, operational plans (action plans), development theme or topic, programming, development services unit, evaluation plan and budget plan. 


\section{PENDAHULUAN}

Tidak dapat dipungkiri, dalam perkembangan anak sering terjadi berbagai hambatan, sehingga terjadinya permasalahan dalam perkembangan selanjutnya. Adanya berbagai hambatan perkembangan anak tentunya membutuhkan bantuan seorang pendidik yaitu melalui penyediaan fasilitas dan stimulus yang tepat dalam perkembangannya.

Berbagai hambatan perkembangan anak yang dominan tampak dari berbagai perilaku anak, sebagaimana disampaikan dalam penelitian Bunu (2012: 115) yang mencakup: 1) masalah sosial meliputi; egois, perilaku sok kuasa, bertengkar, dan agresif, 2) masalah emosional misalnya cemas, pemalu tidak mau berteman canggung, dan takut, 3) masalah moral misalnya; berbuat curang, berbohong, mencuri, dan merusak, 4) masalah kognitif misalnya; kesulitan memahami perkataan orang, dan "lamban" dalam memahami penjelasan, dan 5) masalah bahasa misalnya; perkembangan bicara yang berada di bawah tingkat perkembangan anak seusianya, berbicara cepat sehingga sulit dimengerti, dan memiliki perbendaharaan kata yang relatif sedikit dibandingkan teman seusianya.

Berbagai hambatan perkembangan sebagaimana disampaikan di atas tentunya membutuhkan bantuan agar anak dapat berkembang secara optimal. Upaya ini dapat dilakukan melalui pembinaan baik pada jalur pendidikan formal maupun non formal.Salah satu bentuk pendidikan anak usia dini pada jalur pendidikan formal adalah Taman Kanak-kanak (TK) yang mengambil peran dalam pembinaan untuk memfasilitasi dan menstimulasi perkembangan anak secara optimal. Taman Kanak-kanak bertujuan untuk membantu anak didik mengembangkan berbagai potensi, baik fisik maupun psikis yang salah satunya adalah aspek sosial-emosional anak.

Berdasarkan pertimbangan bahwa masa anak adalah masa emas sekaligus masa kritis, maka upaya memfasilitasi dan menstimulasi harus diberikan secara tepat sesuai tahapannya. Artinya, dalam memfasilitasi dan menstimulasi perkembangan anak harus memperhatikan tugas-tugas perkembangan sesuai rentang usia anak. Di sisi lain, dalam perkembangannya, setiap anak didik di TK memerlukan kesempatan untuk mengembangkan diri melalui proses belajar. Proses belajar ini diperoleh anak melalui interaksinya dengan lingkungan dimana anak berada. Lingkungan yang memungkinkan individu memperoleh proses belajar yang dimaksud adalah tersedianya ekologi perkembangan bagi anak.

Ekologi perkembangan mempunyai peranan penting bagi perkembangan anak. Dengan ekologi perkembangan, berbagai potensi yang ada pada anak dapat difasilitasi, 
sebab ekologi perkembangan anak merupakan segenap lingkungan yang memungkinkan anak memperoleh fasilitas dan stimulus yang tepat, sehingga terjadilah proses belajar secara sehat.Kauchak \& Eggen, 2007: 348-348) menyatakan:

Intervensi untuk membantu perkembangan anak seyogyanya tidak diarahkan hanya kepada anak itu saja melainkan juga kepada lingkungannya, baik lingkungan fisik maupun lingkungan sosialnya sehingga iklim pembelajaran menekankan pada kebermaknaan dan mampu membangkitkan daya kritis dan kreatif anak. Perkembangan intelektual, emosional, sosial, sensoris, dan fisik bukan sematamata akibat struktur biologis yang defektif, melainkan merupakan produk interaksi antara karakteristik struktur biologis dengan variabel lingkungan"

Berdasarkan pandangan Kauchak \& Eggen (2007) di atas, mengisyaratkan bahwa lingkungan sangat berpengaruh pada perkembangan anak. Setiap rentang kehidupan anak, terdapat tugas perkembangan pada setiap aspek yang membutuhkan peran lingkungan dalam optimalisasi pencapaian perkembangannya. Dengan kata lain, lingkungan berpengaruh pada pencapaian tugas perkembangan anak, salah satunya adalah tugas perkembangan terkait aspek sosialemosianal anak.

Perkembangan anak berlangsung secara berkesinambungan yang berarti tingkat perkembangan yang dicapai pada suatu tahap diharapkan meningkat baik secara kuantitatif maupun kualitatif pada tahap selanjutnya. Walaupun setiap anak adalah unik, karena proses perkembangannya berbeda satu sama lain yang dipengaruhi oleh faktor internal (biologis) dan eksternal (lingkungan fisik dan sosial), namun demikian perkembangan anak tetap mengikuti pola yang umum. Agar anak mencapai tingkat perkembangan yang optimal, maka dibutuhkah upaya pembinaan dari berbagai pihak termasuklah konselor di sekolah. Konsekuensinya program bimbingan harus mampu merancang layanan yang dapat memfasilitasi dan menstimulasi pencapaian perkembangan anak dengan mempertimbangkan linkungan yang sehat.

Perkembangan individu akan berlangsung baik apabila adanya keserasian antara pribadi dengan lingkungan. Artinya, harus terdapat lingkungan yang mampu menopang terjadinya perkembangan anak secara sehat. Namun banyak kasus, misalnya adanya kekerasan atau penganiayaan terhadap anak baik kekerasan fisik maupun psikis masih saja terjadi dalam kehidupun anak.

Berdasarkan paparan di atas, semakin jelas bahwa lingkungan sangat berpengaruh pada perkembangan anak. Pentingnya pencapaian tugas perkembangan anak di usia dini serta 
relevansinya dengan pendekatan ekologis dalam optimalisasi tugas perkembangan. Diasumsikan bahwa pendekatan ekologis dapat memfasilitasi dan menstimulasi pencapaian tugas perkembangan aspek sosial anak secara optimal.

Penelitian dilaksanakan di Taman Kanak-kanak (TK) Tunas Harapan Bangsa Kecamatan Sungai Raya Kepulauan Kabupaten Bengkayang. Berdasarkan prasurvey diperoleh informasi bahwa terdapat beberapa kejanggalan terkait dengan tugas perkembangan aspek sosialemosional anak, seperti; terdapat beberapa anak yang sering memukul temannya, meminjam mainan secara paksa, mendorong teman saat bermain, dan terdapat beberapa anak yang selalu ingin didampingi orang tua saat belajar (kondisi ini berlansung hampir satu semester pertama anak masuk sekolah).Anak tidak menunjukkan kooperatif dan empati, seperti anak senang bermain sendiri dan marah ketika barang permainannya di pinjam, dan meminjam mainan secara paksa.

Ekologi perkembangan dikatakan memberikan pengaruh positif bagi anak, sebab ekologi perkembangan dapat memfasilitasi dan menstimulasi perkembangan anak. Lingkungan yang dimaksud adalah lingkungan yang secara langsung maupun tidak langsung dapat memfasilitasi dan menstimulasi terjadi proses belajar anak. Mitchell (2011: 130) menjelaskan teori tentang psikologi ekologis, yang digagas pertama kali oleh Kurt Lewin (1936), yang menitik beratkan pentingnya lingkungan bagi perilaku individu. Peletak dasar teori medan Kurt Lewin menyatakan secara tegas bahwa individu tidak dapat dilepaskan dari struktur sosial dan lingkungan yang melekat dalam kehidupan sehari-hari. Secara matematis, ia menggambarkan bahwa perilaku merupakan perpaduan dua fungsi utama, yaitu organisme dan lingkungan (Rahman, 2006: 2).

Bidang kajian psikologi ekologis adalah perkembangan, dan para spesialis menyoroti bagaimana individu mencerap, memahami, merasakan, membentuk atau dibentuk, dan menilai, yang dipengaruhi oleh lingkungan. Lingkungan perkembangan anak diantaranya dapat berupa lingkungan sosial apakah itu orang tua anak, kakek dan nenek, saudara, guru, atau pihak lain. Dikatakan di atas bahwa, ekologi perkembangan dalam konteks sederhana merupakan segenap lingkungan yang memungkinkan terjadinya interaksi timbal balik sehingga terjadi perubahan kearah yang positif. Tidak semua lingkungan dapat dikatakan ekologi perkembangan. Ekologi perkembangan anak usia dini adalah lingkungan perkembangan yang dapat memfasilitasi segenap aspek dan potensi anak yang 
memungkinkan terjadinya proses pembelajaran. Kartadinata (2009a: 8) menyatakan:

Pendekatan ekologis dibangun berdasarkan asumsi dasar ekologi perkembangan manusia, yakni menciptakan lingkungan yang memberi kesempatan dan kemudahan bagi individu untuk belajar dan berkembang sebagai manusia. Ekologi perkembangan adalah lingkungan belajar, yakni suatu wahana untuk mendeskripsikan, menjelaskan, meramalkan dan mengendalikan interaksi dan transaksi dinamis antara individu (anak didik) dengan lingkungan dan segala perlengkapan yang harus dipelihara.

Pendapat di atas mengisyaratkan bahwa interaksi yang terjadi tidak hanya dengan manusia sebagai lingkungan sosial, tertapi juga lingkungan fisik seperti beberapa perlengkapan (bisa berupa benda fisik atau alam) yang memungkinkan dapat memfasilitasi terjadinya proses belajar anak. Jadi, ekologi perkembangan yang dapat menopang perkembangan anak, dapat berupa lingkungan sosial, maupun lingkungan fisik (benda yang ada di alam). Kedua lingkungan ini memberikan pengaruh bagi anak, baik secara langsung maupun tidak langsung. Lingkungan sosial dengan berbagai nilai, ide atau contoh perilaku yang dapat dipedomanidan dijadikan materi untuk dipelajari.Lingkungan sosial seperti lingkungan keluarga, teman bermain, maupun lingkungan yang lebih luas, (dalam hal ini lingkungan sekolah). Lingkungan sosial ini mempunyai pengaruh yang besar bagi perkembangan dan perilaku anak, oleh karena itu dalam memahami dan membantu perkembangan anak lingungan sosial penting untuk di kondisikan sebagai lingkungan sosial yang sehat bagi perkembangan anak. Rahman (2006: 3) menyatakan "teori ekologi ini dapat dijadikan pijakan teoretis dalam menganalisis kebuntuan pemahaman dan pendekatan kita terhadap masalah individu dan relasinya dengan lingkungan”. Sementara, alam dapat dimanfaatkan sebagai ekologi yang memungkinkan anak memahami berbagai konsep maupun fenomena yang terjadi didunia yang nantinya berguna ketika mereka dewasa.

Secara struktural di TK Tunas Harapan Bangsa Kecamatan Sungai Raya Kepulauan Kabupaten Bengkayang layanan bimbingan sudah mempertimbangkan lingkungan dalam proses pembelajaran, akan tetapi belum terorganisasi secara rinci dalam rangka memaksimalkan ketercapaian tugas perkembangan secara optimal. Oleh karena itu, peneliti merasa perlu adanya rancangan program bimbingan dan konseling yang disusun secara rinci yang benar-benar menyentuh tugas perkembangan aspek sosial-emosional dengan mempertimbangkan ekologi perkembangan anak. Upaya tersebut akan peneliti rumuskan dalam rancangan 
"Bimbingan dengan Pendekatan Ekologis untuk Memaksimalkan Pencapaian Tugas Perkembangan Aspek Sosial-Emosional Anak Taman Kanak-kanak (TK).

Oleh karena itu yang menjadi fokus masalah pada penelitian ini adalah "Bagaimana rancangan bimbingan untuk mengoptimalkan pencapaian tugas perkembangan aspek sosial-emosional anak kelompok A Taman Kanak-kanak TK Tunas Harapan Bangsa Kecamatan Sungai Raya Kepulauan Kabupaten Bengkayang?’. Tujuan penelitian ini adalah merancang bimbingan untuk mengoptimalkan pencapaian tugas perkembangan aspek sosial-emosional anak Kelompok A Taman Kanak-kanak TK Tunas Harapan Bangsa Kecamatan Sungai Raya Kepulauan Kabupaten Bengkayang.

\section{METODE}

Penelitian bimbingan dengan pendekatan ekologis untuk memaksimalkan pencapaian tugas perkembangan aspek sosial-emosional anak Taman Kanak-kanak (TK) dilakukan dengan menggunakan pendekatan kualitatif. Samsudi (2009: 119) menyarankan beberapa prinsip yang harus dipenuhi apabila ingin menganalisis data kualitatif, yaitu:

a. Naturalistik: yakni, analisis data harus mendasarkan situasi nyata yang berubah secara alamiah, terbuka dan tidak ada rekayasa pengontrolan variabel

b. Analisis induktif: yakni dengan mendasarkan prosedur berfikir induksi, dimensi, hubungan penting dan asli, yang diungkap melalui pertanyaan terbuka.

c. Holistik: artinya totalitas fenomena harus dipahami oleh peneliti dan tidak dilihat secara parsial.

Berdasarkan saran sebagaimana disampaikan oleh Samsudi (2009) tersebut, dalam rangka mendeskripsikan data secara akurat yang terkait dengan upaya guru TK Tunas Harapan Bangsa Kecamatan Sungai Raya Kepulauan Kabupaten Bengkayang memanfaatkan lingkungan belajar dalam memaksimalkan tercapainya tugas perkembangan aspek sosial-emosional anak TK Tunas Harapan Bangsa Kecamatan Sungai Raya Kepulauan Kabupaten Bengkayang, maka untuk menganalisis data kualitatif pada penelitian ini beracuan pada ketiga prinsip tersebut. Penggunaan ketiga prinsip tersebut berdasarkan pertimbangan bahwa: (1) data yang dikumpulkan merupakan data deskriptif yaitu berupa kata-kata dan tindakan-tindakan subyek yang diwawancarai atau diamati; (2) penelitian ini memberikan gambaran apa adanya mengenai upaya guru TK Tunas Harapan Bangsa Kecamatan Sungai Raya Kepulauan Kabupaten Bengkayang dalam memaksimalkan tercapainya tugas 
perkembangan aspek sosial-emosional anak TK Tunas Harapan Bangsa Kecamatan Sungai Raya Kepulauan Kabupaten Bengkayang yang menjadi subyek penelitian; (3) penelitian ini bermaksud mengungkapkan peristiwa-peristiwa yang alami tanpa ada rekayasa atau manipulasi; (4) aspek-aspek yang dikaji dapat dipelajari secara mendalam, menyeluruh dan terinci berdasarkan prilaku yang diobservasi.

Berdasarkan permasalahan yang ingin diungkap maka metode penelitian yang digunakan dalam penelitian ini adalah metode penelitian deskriptif dengan bentuk penelitian adalah studi kasus (case study). Pemilihan metode dan bentuk penelitian ini berdasarkan pertimbangan bahwa penelitian ini ingin memahami secara lebih mendalam suatu fenomena khusus atas suatu hal atau peristiwa yang unik yaitu terkait upaya guru TK Tunas Harapan Bangsa Kecamatan Sungai Raya Kepulauan Kabupaten Bengkayang memanfaatkan lingkungan dalam memaksimalkan tercapainya tugas perkembangan aspek sosial anak TK Tunas Harapan Bangsa Kecamatan Sungai Raya Kepulauan Kabupaten Bengkayang.

Dalam studi kasus penelitian akan menfokuskan penemuan (discovery), wawasan (insight) dan pemahaman (understanding) dalam suatu peristiwa atau kasus secara intensif, rinci dan mendalam.
Subana dan Sudrajat (2005:

menyebutkan salah satu metode penelitian khususnya bentuk penelitian deskriptif adalah Studi Kasus (case study), yaitu bentuk penelitian memusatkan pada suatu kasus secara intensif dan mendetail. Berdasatkan studi kasus,selanjutnya peneliti mencoba untuk merancang bimbingan untuk mengoptimalkan pencapaian tugas perkembangan aspek sosial-emosional anak Kelompok A Taman Kanak-kanak TK Tunas Harapan Bangsa Kecamatan Sungai Raya Kepulauan Kabupaten Bengkayang.

Prosedur penelitian bimbingan dengan pendekatan ekologis untuk memaksimalkan pencapaian tugas perkembangan aspek sosial-emosional anak Taman Kanak-kanak (TK) dijelaskan pada paparan berikut:

1. Pemilihan kasus: pemilihan kasus ini didasari penemukan informasi empirik terutama terkait strategi, prinsip-prinsip, struktur lingkungan atau sistem manajemen dalam pelaksanaan intervensi bimbingan untuk meningkatkan ketercapaian tugas perkembangan aspek sosial-emosional anak kelompok A TK Tunas Harapan Bangsa Kecamatan Sungai Raya Kepulauan Kabupaten Bengkayang.

2. Pengumpulan data: dalam pengumpulan data digunakan metode observasi, wawancara, dan analisis dokumentasi. Melalui observasi secara cermat diamati berbagai kesulitan terkait perkembangan 
anak pada aspek sosial-emosional, terkait fenomena budaya, lingkungan sosial, fisik maupun spiritual dalam proses bimbingan di TK Tunas Harapan Bangsa Kecamatan Sungai Raya Kepulauan Kabupaten Bengkayang. Sehingga dalam observasi ini lebih menyangkut pada penggalian data-data yang bersifat kongrit dan empirik. Sedangkan data-data yang bersifat abstrak menyangkut makna, pandangan hidup atau nilai peneliti memperdalamnya dengan metode wawancara kepada informan.

3. Penganalisisan data: Data yang terkumpul diabstaksikan (agregasi), mengorganisasi, dan mengklasifikasi data. Agregasi merupakan proses mengabstraksi hal-hal khusus menjadi hal-hal umum guna menemukan pola umum data. Data dapat diorganisasi secara kronologis, kategori atau dimasukkan ke dalam tipologi. .

4. Perbaikan data: meskipun semua data telah terkumpul, dalam pendekatan studi kasus tetap dilakukan upaya penyempurnaan data baru terhadap kategori yang telah ditemukan. Oleh karena itu, tidak menutup kemungkinan untuk kembali ke lapangan, membuat kategori baru untuk menyempurnakannya.

5. Penyusunan laporan: dalam penulisan laporan ini dideskripsikan suatu gejala atau kesatuan sosial secara jelas, sehingga kredeibilitas penelitian kuat dan rnemudahkan pembaca mernahami seluruh informasi penting dari hasil penelitian.

Sedangkan dalam rangka merancang program bimbingan untuk mengoptimalkan pencapaian tugas perkembangan aspek sosial anak Kelompok A TK Tunas Harapan Bangsa Kecamatan Sungai Raya Kepulauan Kabupaten Bengkayang, yang menjadi subyek penelitian adalah anak Kelompok A yang secara resmi tercatat sebagai siswa TK Tunas Harapan Bangsa Kecamatan Sungai Raya Kepulauan Kabupaten Bengkayang.

Penelitian ini menggunakan teknik komunikasi langsung dan teknik komunikasi tidak langsung, serta studi dokumentasi.Berdasarkan pertimbangan bahwa penelitian ini merupakan penelitian kualitatif, instrumen penelitian atau yang bertindak sebagai alat pengumpul data adalah peneliti itu sendiri.Dalam penyelenggaraanya (pengumpulan data) peneliti sendiri yang terjun langsung dalam lokasi penelitian untuk merekam data selama penelitian. Proses pengumpulan data peneliti menggunakan tiga teknik yaitu; observasi, wawancara dan studi dokumentasi.

Teknik analisis data dalam penelitian ini menggunakan analisis interaktif model Miles and Huberman. Aktivitas dalam analisis datanya yaitu reduksi data, penyajian data, dan kesimpulan. 1) reduksi data berarti merangkum, memilih hal-hal yang pokok, memfokuskan pada hal-hal yang penting, dicari tema dan polanya dan membuang yang 
tidak perlu, 2) penyajian data dimaksudkan agar lebih mempermudah bagi peneliti untuk dapat melihat gambaran secara keseluruhan atau bagian-bagian tertentu dari data penelitian, 3) kesimpulan/verifikasi, kesimpulan yang dikemukakan pada tahap awal didukung oleh bukti-bukti yang valid dan konsisten saat peneliti kembali ke lapangan mengumpulkan data, maka kesimpulan yang dikemukakan merupakan kesimpulan yang kredibel.

Studi terkait dengan; 1) Gambaran atau kondisi lingkungan yang mendukung pencapaian tugas perkembangan aspek sosial-emosional anak kelompok A TK Tunas Harapan Bangsa Kecamatan Sungai Raya Kepulauan Kabupaten Bengkayang, 2) Informasi tentang upaya guru TK Tunas Harapan Bangsa Kecamatan Sungai Raya Kepulauan Kabupaten Bengkayang memanfaatkan lingkungan belajar dalam memaksimalkan tercapainya tugas perkembangan aspek sosial-emosional anak TK Tunas Harapan Bangsa Kecamatan Sungai Raya Kepulauan Kabupaten Bengkayang, dan studi terkat 3) informasi mengenai kendala-kendala yang dihadapi guru TK Tunas Harapan Bangsa Kecamatan Sungai Raya Kepulauan Kabupaten Bengkayang dalam memaksimalkan pencapaian tugas perkembangan aspek sosial-emosional anak kelompok A TK Tunas Harapan Bangsa Kecamatan Sungai Raya Kepulauan Kabupaten Bengkayang dilakukan dengan analisis interaktif yaitu teknik wawancara, dengan cara memilah atau merangkum data hasil wawancara evaluasi layanan informasi BK di sekolah, menyajikan data dalam bentuk persentase dan menyimpulkan hasil wawancara.

Sedangkan studi terkait ketercapaian tugas perkembangan aspek sosial-emosional anak kelompok A TK Tunas Harapan Bangsa Kecamatan Sungai Raya Kepulauan Kabupaten Bengkayang pengumpulan data yang dilakukan melalui observasi dilakukan dengan analisis interaktif yaitu teknik panduan observasi dengan skala, menyajikan data dalam bentuk rata-rata, grafik dan persentase serta menginterpretasikannya dalam bentuk deskripsi terkait ketercapaian tugas perkembangan.

\section{HASIL DAN PEMBAHASAN}

Taman Kanak-kanak (TK) Tunas Harapan Bangsa Sungai Raya Kepulauan kabupaten Bengkayang secara resmi berdiri pada tanggal 8 Mei 2007 berdasarkan surat persetujuan penyelenggaraan sekolah swasta nomor 58/KEP/2008 dari Dinas Pendidikan Nasional Kota Pontianak Provinsi Kalimantan Barat.

Taman Kanak-kanak (TK) Tunas Harapan Bangsa Sungai Raya Kepulauan kabupaten Bengkayang merupakan sekolah Islam terpadu yang menjadi salah satu model sekolah alternatif. TK Tunas Harapan 
Bangsa Sungai Raya Kepulauan kabupaten Bengkayang menerapkan pendekatan penyelenggaraan proses pembelajaran yang memadukan pendidikan umum dengan pendidikan nilai-nilai agama Islam dalam suatu bangunan kurikulum. Dengan pendekatan ini, semua pelajaran dan kegiatan sekolah tidak lepas dari bingkai ajaran dan pesan nilai Islam.

Sekolah alternatif dengan memadukan pendidikan umum dengan pendidikan nilainilai agama Islam sangat baik di terapkan pada usia dini. Sudrajat (2001: 48) menegaskan "pada umumnya agama, seseorang di ditentukan oleh pengalaman pendidikan, pengalaman dan latihan yang dilaluinya sejak kecil”. Penekanan dalam hal keterpaduan ini menuntut kemampuan guru guru dalam mengembangkan pendekatan proses pembelajaran yang kaya, variatif dan menggunakan media serta sumber belajar yang luas dan luwes.

Pada saat ini TK Tunas Harapan Bangsa Sungai Raya Kepulauan kabupaten Bengkayang mempunyai 2 kelas masingmasing untuk kelo dan B. Adapun sarana prasarana yang dimiliki TK Tunas Haraya Kepulauan kabupaten Bengkayang dipaparkan pada tabel 4.1 berikut:

Tabel 4.1

Sarana Prasarana TK Tunas Harapan Bangsa Sungai Raya Kepulauan Kabupaten Bengkayang

\begin{tabular}{|c|c|c|c|c|c|}
\hline \multicolumn{3}{|c|}{ SARANA PRASARANA } & \multicolumn{3}{|c|}{ JUMLAH } \\
\hline $\begin{array}{c}\text { GEDUNG/LOKAL } \\
\text { (A1) }\end{array}$ & $\begin{array}{c}\text { AREA BERMAIN } \\
\text { (A2) }\end{array}$ & $\begin{array}{l}\text { AREA TAMAN } \\
\text { HIJAU (A3) }\end{array}$ & (A1) & (A2) & (A3) \\
\hline Ruang Kelas & Ayunan & Halaman & 2 & 1 & 1 \\
\hline Ruang Kantor & Tangga Pelangi & & - & - & \\
\hline Ruang Guru & Papan Luncur & & 1 & 1 & \\
\hline Ruang Perpustakaan & Bak Pasir & & - & 1 & \\
\hline Ruag UKS & Ruang Indor & & 1 & 1 & \\
\hline Ruang Audio Visual & Balok Titian & & 1 & & \\
\hline Ruang Dapur & & & 1 & & \\
\hline Kamar Mandi & & & - & & \\
\hline & Total & & 6 & 4 & 1 \\
\hline
\end{tabular}

Sumber: TU TK Tunas Harapan Bangsa Sungai Raya Kepulauan

Sarana dan prasarana yang memadai menjadi syarat yang penting untuk menyelenggarakan pendidikan dalam rangka mencapai tujuan yang telah dirumuskan. Berdasarkan Petunjuk Teknis Penyelenggarakan Taman Kanak-kanak
Direktorat Jendral Pendidikan Anak Usia Dini pada pembahasan Bab 2: Syaratsyarat dan Tata Cara pendirian TK Sub (2011: 9) tentang Persyaratan Sarana dan Prasarana, menegaskan persyaratan sarana dan prasarana meliputi memiliki ruang 
kelas, ruang kantor/kepala TK, ruang dapur, gudang, kamar mandi/WC guru, ruang UKSdan kamar mandi/WC anak", dapat disimpulkan bahwa, sarana dan prasarana di TK Tunas Harapan Bangsa Sungai Raya Kepulauan kabupaten Bengkayang memenuhi persyaratan untuk untuk melaksanakan proses pembelajaran anak.

Adapun data anak kelompok A tahun ajaran 2013-1014 yang dilihat dari jumlah anak dan jenis kelaminnya dipaparkan pada tabel 4.2 berikut:

Tabel 4.2: Data Anak Kelompok A Berdasarkan Jenis KelaminTahun Pelajaran 2013/2014

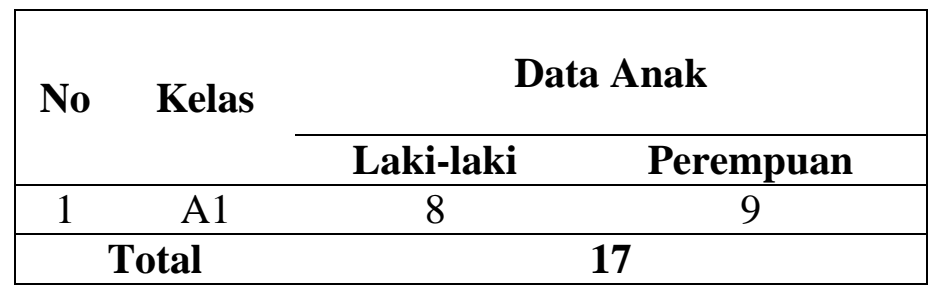

Sumber: Tata Usaha TK Tunas Harapan Bangsa Sungai Raya Kepulauan kabupaten Bengkayang

Berdasarkan data pada tabel 4.2 di atas, dilihat dari rasio anak pada masingmasing kelas dapat diindikasikan bahwa di TK Tunas Harapan Bangsa Sungai Raya Kepulauan kabupaten Bengkayang mendekati ideal untuk penyelenggaran pembelajaran. Diindikasikan ideal atas dasar pertimbangan bahwa, rombongan belajar untuk PAUD jalur pendidikan formal jumlah maksimal peserta didik setiap rombongan belajar sebanyak 20 peserta didik, (Permendiknas nomor 58 tahun 2009 tentang Standar Pendidikan Anak Usia Dini (PAUD).

Jumlah guru TK Tunas Harapan Bangsa Sungai Raya Kepulauan kabupaten Bengkayang sebanyak 3 orang dengan jabatan masing masing merangkap jabatan sebagai 1 kepala sekolah, 1 wali kelas sekaligus guru kelas dan 1 guru pendamping. Berdasarkan perbandingan rasio guru BK dengan jumlah anak maka dapat disimpulkan di TK Tunas Harapan Bangsa Sungai Raya Kepulauan kabupaten Bengkayang ideal untuk menyelenggaran program bimbingan dan konseling.

Rancangan bimbingan dan konseling dengan pendekatan ekologis untuk memaksimalkan tugas perkembangan aspek sosial-emosional TK Tunas Harapan Bangsa Sungai Raya Kepulauan kabupaten Bengkayang dimulai dari perumusan rasional, perumusan visi dan misi, pengertian, deskripsi kebutuhan, perumusan tujuan, rencana operasional (action plan), pengembangan tema atau topik, perumusan program, pengembangan 
satuan layanan, rencana evaluasi dan rencana anggaran.

Peneliti dalam merumuskan rasional program bimbingan dan konseling melalui pendekatan ekologi bertolok ukur dari pandangan bahwa pada hakikatnya anak usia dini merupakan masa emas sekaligus masa kritis pada setiap tahapannya, sehingga diperlukan pembinaan yang tepat sesuai tahapannya dan tugas perkmbangannya. Pembinaan yang dilakukan tentunya melalui proses pendidikan, sehingga profesi bimbingan dan konseling yang berkecimpung dalam dunia pendidikan dirasakan mendesak untuk ikut berperan.

Setelah rasional pogram bimbingan dan konseling melalui pendekatan ekologi dirumuskan, langkah selanjutnya yang peneliti lakukan adalah merumuskan visi, misi bimbingan dan konsling. Berdasarkan deskripsi rasional, maka yang menjadi visi, misi dan tujuan program bimbingan dan konseling secara keseluruhan adalah dalam upaya membantu menstimulasi dan memfasilitasi ketercapaian tugas-tugas perkembangan anak.Tujuan program bimbingan dan konseling yang dirumuskan, tentunya berdasarkan asesmen kebutuhan yang telah dilakukan.Selain itu, rumusan visi-misi bimbingan dan konseling juga mempertimbangkan visi misi dan tujuan pendidikan nasional dan juga visi misi dan tujuan TK Tunas Harapan Bangsa Sungai Raya Kepulauan kabupaten Bengkayang.

Dalam rangka menghindari kesalahpahaman dalam memaknainya, dan memberikan batasan kharakteristik khas suatu program, maka peneliti mendefinisikan program bimbingan dan konseling melalui pendekatan ekologi sebagai serangkaian rencana layanan bimbingan dan konseling yang dirancang dalam rangka memfasilitasi dan menstimulasi pencapaian tugas perkembangan anak secara optimal. Program bimbingan dan konseling berbsis tugas-tugas pekembangan di TK Tunas Harapan Bangsa Sungai Raya Kepulauan kabupaten Bengkayang dirumuskan beracuan pada karakteristik (pengetahuan, keterampilan, kemampuan dan perilaku) yang dicapai anak. Sistematika pengembangan program bimbingan dan konseling melalui pendekatan ekologi meliputi: rasional, perumusan visi dan misi, deskripsi kebutuhan, perumusan tujuan, perumusan program, rencana operasional, pengembangan tema atau topik, pengembangan satuan layanan, dan rencana evaluasi.

Berdasarkan need assesment ketercapaian tugas-tugas perkembangan di Taman Kanak-kanak (TK) Tunas Harapan Bangsa Sungai Raya Kepulauan kabupaten Bengkayang diidentifikasi adanya beberapa anak kelompok A dengan 
Tingkat Ketercapaian Tugas

Perkembangan (TKTP) termasuk kategori "rendah" dan "sangat rendah". Dari itu, dibutuhkan fasilitasi dan stimulusi berupa layanan bimbingan dan konseling yang terpogram berdasarkan kebutuhan perkembangan anak, dalam arti sesuai dengan tugas perkembangan yang seharusnya dipenuhi sesuai tahapannya.Harapannya anak dapat berkembang secara optimal.

Tolok ukur kebutuhan anak terhadap layanan bimbingan dan konseling, dalam penyusunan programnya (Program Bimbingan dan Konseling Melalui pendekatan ekologi) tidak hanya diprogramkan untuk anak dengan TKTP yang rendah saja. Dalam rangka menjalakan fungsi pemeliharaan bimbingan dan konseling, maka program bimbingan dan konseling melalui pendekatan ekologi diprogramkan untuk semua anak baik TKTP yang rendah maupun TKTP yang tinggi.

Berdasarkan need assesment yang dilaksanakan, maka kebutuhan layanan bimbingan dan konsling dapat dideskripsikan sebagai berikut:

a. Anak kelompok A secara keseluruhan membutuhkan alokasi waktu layanan bimbingan dan konseling lebih banyak untuk mengembangkan aspek mencapai kestabilan fisiologis indikator keterampilan motorik halus dan aspek mencapai pemahaman sederhana mengenai kenyataan sosial dan fisik.

b. Anak S62 dan S64 membutuhkan prioritas layanan bimbingan dan konseling secara khusus. Berdasarkan pertimbangan bahwa hampir semua aspek tugas perkembangan kedua anak terseebut dengan TKTP yang rendah.

c. Beberapa anak membutuhkan prioritas layanan bimbingan dan konseling secara khusus dalam rangka mendapatkan bantuan mencapai TKTP lebih tingi pada masing-masing aspek dan indikator tugas perkembangan mereka yang rendah (terdapat pada Tabel 4.63 Klasifikasi Tingkat Ketercapaian Tugas Perkembangan Anak Kelompok A)

d. Semua anak dengan TKTP termasuk kategori "tinggi" dan "sangat tinggi" membutuhkan layanan bimbingan dan konseling agar TKTP lebih optimal.

Selain kebutuhan layanan bimbingan dan konseling dianalisis dari aspek kondisi anak sebagaimana dipaparkan di atas, kebutuhan akan layanan bimbingan dan konseling juga dianalisis dari aspek lingkungan, baik lingkungan sosial maupun linkungan fisik yang baik secara lansung muapun tidak dapat berpengaruh bagi perkembangan anak. Berdasarkan hasil wawancara dengan guru yang dalam hal ini adalah ekologi perkembangan yang 
mencakup lapisan mikro

(keluarga/orang tua), lapisan meso

(lingkungan fisik/alam sekolah,

kelompok sebaya, sistem nilai, norma

masyarakat, stereotip, stigma sosial, dan

struktur politik, ideologi, lingkungan

global). Beberapa kebutuhan

lingkungan terkait ekologi

perkembangan yang dimaksud dapat

dipaparkan pada Tabel 1 di bawah ini:

lain-lain), dan lapisan makro (seperti

Tabel 1: Deskripsi Kebutuhan Lingkungan

\begin{tabular}{|c|c|c|}
\hline No & Kondisi Lingkungan & Deskripsi Kebutuhan Lingkungan \\
\hline 1 & $\begin{array}{l}\text { Kurangnya pemahaman orang tua terkait } \\
\text { program sekolah dan peran anak dalam } \\
\text { mensukseskan program sekolah }\end{array}$ & Perlu adanya sosialisasi program \\
\hline 2 & $\begin{array}{l}\text { Kurangnya pemahaman orang tua terkait } \\
\text { hal-hal terpenting terkait dengan } \\
\text { perkembangan anak (seperti sistem } \\
\text { pengasuhan, kondisi wajar dan tidak } \\
\text { wajar yang terjadi dalam tumbuh } \\
\text { kembang anak) }\end{array}$ & $\begin{array}{l}\text { Perlu adanya program untuk pendidikan } \\
\text { orang tua. }\end{array}$ \\
\hline 3 & $\begin{array}{l}\text { Kondisi gedung dan ruangan untuk } \\
\text { penyelenggaraan pembelajaran kurang } \\
\text { baik. }\end{array}$ & $\begin{array}{l}\text { Perlu pembenahan kondisi gedung dan } \\
\text { ruangan yang nyaman dansesui dengan } \\
\text { jiwa anak }\end{array}$ \\
\hline 4 & $\begin{array}{l}\text { Kurangnya Alat Permainan Edukatif } \\
\text { (APE) atau media pembelajaran yang } \\
\text { terkait untuk mengembangkan aspek } \\
\text { sosial emosional anak }\end{array}$ & $\begin{array}{l}\text { Perlu penyediaan APE dan Media yang } \\
\text { pembelajaran untuk menstimulasi dan } \\
\text { memfasilitasi pekembangan tugas } \\
\text { perkembangan aspek sosial-emosional } \\
\text { anak }\end{array}$ \\
\hline 5 & $\begin{array}{l}\text { Beberapa teman bermain anak berasal } \\
\text { dari latar belakang keluarga yang } \\
\text { Brooken Home }\end{array}$ & $\begin{array}{l}\text { Perlu adanya program khusus untuk } \\
\text { mengurangi dampak dari keluarga Brooken } \\
\text { Home }\end{array}$ \\
\hline 6 & $\begin{array}{l}\text { Beberapa teman bermian anak } \\
\text { mempunyai kecendrungan sikap kurang } \\
\text { kooperatif, empati dan senang } \\
\text { menyendiri }\end{array}$ & $\begin{array}{l}\text { Perlu pengondisian suasanan bermain } \\
\text { sesama teman atau interaksi sesama teman }\end{array}$ \\
\hline 7 & $\begin{array}{l}\text { Proses pembelajaran kurang } \\
\text { memanfaatkan nilai-nilai budaya sesuai } \\
\text { kondisi latar belakang budaya anak. }\end{array}$ & $\begin{array}{l}\text { Perlu pengondisian suasanan bermain } \\
\text { sesama teman atau interaksi sesama teman }\end{array}$ \\
\hline & $\begin{array}{lll}\text { Selanjutnya } & \text { TKTP } & \text { tersebut }\end{array}$ & yang telah diprioritaskan sebagaimana \\
\hline
\end{tabular}


Tabel: 2

Komponen dan Strategi Layanan yang Diprioritaskan

\begin{tabular}{|c|c|c|c|c|}
\hline No & $\begin{array}{c}\text { Komponen } \\
\text { Layanan }\end{array}$ & Strategi Layanan & Keterangan & Tujuan \\
\hline \multirow[t]{4}{*}{1} & $\begin{array}{l}\text { Kurikulum } \\
\text { Bimbingan/Layan } \\
\text { an Dasar }\end{array}$ & $\begin{array}{l}\text { a. } \\
\text { Bimbingan Klasikal } \\
\text { 1) layanan informasi }\end{array}$ & Prioritas & $\begin{array}{l}\text { Dirancang untuk pencapaian } \\
\text { tugas perkembangan anak }\end{array}$ \\
\hline & & 2) layanan orientasi & Prioritas & $\begin{array}{l}\text { Dirancang untuk pencapaian } \\
\text { tugas perkembangan anak }\end{array}$ \\
\hline & & a. bimbingan kelompok & - & - \\
\hline & & $\begin{array}{l}\text { b. } \\
\text { Program pendidikan } \\
\text { Orang tua }\end{array}$ & - & - \\
\hline \multirow[t]{7}{*}{2} & $\begin{array}{l}\text { Layanan } \\
\text { Responsif }\end{array}$ & $\begin{array}{ll}\text { a. } & \\
& \text { Konseling individual }\end{array}$ & Kondisional & \\
\hline & & $\begin{array}{ll}\text { b. } & \\
& \text { Konseling kelompok }\end{array}$ & - & - \\
\hline & & $\begin{array}{ll}\text { c. } & \\
\text { Konseling Krisis }\end{array}$ & - & - \\
\hline & & $\begin{array}{l}\text { d. } \\
\text { Referal (alih tanggapan } \\
\text { kasus) }\end{array}$ & Kondisional & \\
\hline & & e. Bimbingan Teman Sebaya & - & - \\
\hline & & $\begin{array}{l}\text { f. } \\
\text { Konferensi Kasus }\end{array}$ & Kondisonal & $\begin{array}{l}\text { Membicarakan pemecahan } \\
\text { masalah perkembangan anak } \\
\text { bersama kepala sekolah, wali } \\
\text { kelas, guru kelas atau orang tua } \\
\text { anak }\end{array}$ \\
\hline & & $\begin{array}{l}\text { g. } \\
\text { Home Visit }\end{array}$ & Prioritas & $\begin{array}{l}\text { Memperaleh data atau informasi } \\
\text { lebih lanjut tentang anak }\end{array}$ \\
\hline \multirow[t]{2}{*}{3} & $\begin{array}{l}\text { Perencanaan } \\
\text { individual }\end{array}$ & $\begin{array}{l}\text { a. } \\
\text { Penilaian individual atau } \\
\text { kelompok (Individual or } \\
\text { Small Group Apraisal). }\end{array}$ & Prioritas & $\begin{array}{l}\text { Konselor membantu anak } \\
\text { menilai kelemahan dan } \\
\text { kelebihan yang ada pada anak } \\
\text { terkait dengan aspek pribadi- } \\
\text { sosial anakyang kemudian di } \\
\text { konsulltasikan kepada orang tua } \\
\text { anak }\end{array}$ \\
\hline & & $\begin{array}{l}\text { b. } \\
\text { Individual or Small-Group } \\
\text { Advicement. }\end{array}$ & Prioritas & $\begin{array}{l}\text { Mengkonsultasikan dan } \\
\text { memberikan nasihat kepada } \\
\text { orang tua untuk memanfaatkan } \\
\text { hasil penilaian atas anaknya } \\
\text { memfasilitasi orang tua atau } \\
\text { anak (layanan penempatan atau } \\
\text { penyaluran) dalam rangka } \\
\text { memanfaatkan hasil penilaian }\end{array}$ \\
\hline \multirow[t]{2}{*}{4.} & Dukungan Sistem & $\begin{array}{l}\text { a. } \\
\text { Pengembangan staf }\end{array}$ & - & Meningkatkan profesionalitas \\
\hline & & $\begin{array}{l}\text { b. } \\
\text { Konsultasi dan kolaborasi }\end{array}$ & Prioritas & $\begin{array}{l}\text { Mengkonsultasikan dengan } \\
\text { kepala sekolah, guru, orang tua, } \\
\text { dan pihak lain dalam rangka } \\
\text { membangun persamaan persepsi } \\
\text { dalam memenuhi kebutuhan } \\
\text { pencapaia tugas perkembangan }\end{array}$ \\
\hline
\end{tabular}




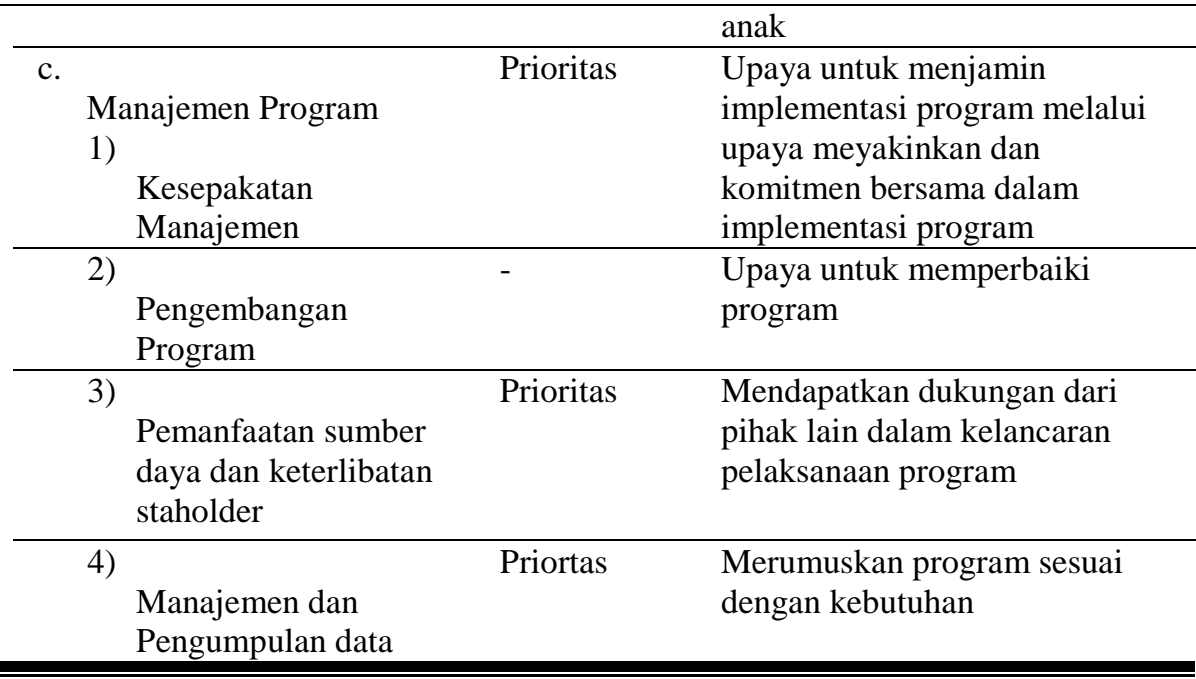

\begin{tabular}{cl}
\hline \hline Materi bimbingan yang dirancang & kabupaten Bengkayang dipaparkan pada \\
untuk anak kelompok A di TK Tunas & Tabel 3 di bawah ini:
\end{tabular}

Harapan Bangsa Sungai Raya Kepulauan

Tabel 3 : Pengembangan Tema atau Topik Materi Layanan Bimbingan dan Konseling`dengan Pendekatan Ekologi untuk Memaksimalkan Tugas Perkembangan Aspek Sosial-Emosional

\begin{tabular}{|c|c|c|}
\hline Kompetensi & $\begin{array}{c}\text { Tujuan Layanan Bimbingan dan } \\
\text { Konseling }\end{array}$ & $\begin{array}{c}\text { Tema atau Topik } \\
\text { Materi Layanan Bimbingan dan } \\
\text { Konseling }\end{array}$ \\
\hline \multirow{6}{*}{$\begin{array}{l}\text { Belajar } \\
\text { mengelola } \\
\text { emosi dalam } \\
\text { berinteraksi } \\
\text { dan } \\
\text { bersosialisasi } \\
\text { dengan } \\
\text { lingkungan } \\
\text { terdekatnya }\end{array}$} & $\begin{array}{l}\text { 1. Membantu anak belajar untuk memahami } \\
\text { peran seks. }\end{array}$ & $\begin{array}{l}\text { a. Siapa Diriku dan Keluargaku } \\
\text { (menyebutkan nama dan jenis kelamin) } \\
\text { b. Permainan Bongkar Pasang Gambar } \\
\text { Manusia } \\
\text { c. Kebutuhanku (Pakaian Ibadahku) }\end{array}$ \\
\hline & $\begin{array}{l}\text { 2. Membimbing dan melatih anak agar dapat } \\
\text { menunjukkan kooperatif dan empati } \\
\text { terhadap orang lain di lingkungan } \\
\text { sekitarnya }\end{array}$ & $\begin{array}{l}\text { a. Aku suka Berteman } \\
\text { b. Tidak Mengganggu Teman } \\
\text { c. Aku Senang Meminjamkan Mainanku } \\
\text { d. Berbagi Makanan dengan Teman } \\
\text { e. Mengunjungi Teman Ketika Sakit } \\
\text { f. Cerita Keagamaan }\end{array}$ \\
\hline & $\begin{array}{l}\text { 3. Membantu anak dapat mengekspresikan } \\
\text { mengenai perasaan diri sendiri dan orang } \\
\text { lain. }\end{array}$ & $\begin{array}{l}\text { a. Kesukaanku (Anak menceritakan } \\
\text { kesukaannya di depan kelas secara } \\
\text { bergiliran) } \\
\text { b. Bermain Peran (Mencontohkan orang } \\
\text { ketawa, orang menangis, orang sedih, } \\
\text { orang lagi ngantuk) } \\
\text { c. Cerita Keagaan (diiringi dengan } \\
\text { pertanyaan tau penjelasan) }\end{array}$ \\
\hline & $\begin{array}{l}\text { 4. Membantu anak belajar berinteraksi } \\
\text { dengan teman sepermainan dilingkungan } \\
\text { terdekatnya. }\end{array}$ & $\begin{array}{l}\text { a. Belajar Bersama } \\
\text { b. Bermain Bersama } \\
\text { c. Berkunjung Kerumah Teman }\end{array}$ \\
\hline & $\begin{array}{l}\text { 5. Membantu anak mengembangkan rasa } \\
\text { ingin tahu dan kepedulian tentang suasana } \\
\text { sosial yang ada disekitarnya }\end{array}$ & $\begin{array}{l}\text { a. Aku Senang Membantu } \\
\text { b. Cerita Keagamaan } \\
\text { c. Kunjungan Tetempat-tempat Sosial }\end{array}$ \\
\hline & 6. Membantu anak belajar mengembangkan & a. Bercerita Pengalaman Liburan \\
\hline
\end{tabular}




\begin{tabular}{|c|c|c|}
\hline Kompetensi & $\begin{array}{c}\text { Tujuan Layanan Bimbingan dan } \\
\text { Konseling }\end{array}$ & $\begin{array}{c}\text { Tema atau Topik } \\
\text { Materi Layanan Bimbingan dan } \\
\text { Konseling }\end{array}$ \\
\hline & $\begin{array}{l}\text { dan mengekspresikan emosi dalam } \\
\text { berkomunikasi. }\end{array}$ & $\begin{array}{l}\text { b. Kesukaanku (Anak bercerita tenntang } \\
\text { kesukaanya) }\end{array}$ \\
\hline & $\begin{array}{l}\text { 7. Membantu anak belajar mengembangkan } \\
\text { rasa percaya diri. }\end{array}$ & $\begin{array}{l}\text { a. Aku Bisa Menggunakan Pakaian } \\
\text { Sekolah Sendiri } \\
\text { b. Aku Bisa Mandi Sendiri } \\
\text { c. Pemberian reinforcement saat belajar } \\
\text { atau bermain } \\
\text { d. Menyikat Gigi Sampai Bersih }\end{array}$ \\
\hline
\end{tabular}

\section{SIMPULAN}

Secara umum kondisi lingkungan di TK Tunas Harapan Bangsa kurang mendukung untuk memaksimalkan pencapaian tugas perekembangan aspek sosial emosional anak.Dapat dilihat dari kondisi sarana dan prasarana yang belum memadai.Upaya yang dilakukan guru TK Tunas Harapan Bangsa belum optimal dilaksanakan ditinjau dari sudut pandang guru sebagai fasilitator dan belum tersedianya rancangan bimbingan secara khusus untuk membantu mengoptimalkan pencapaian tugas perkembangan sosial anak.Racangan program disusun berdasarkan kebutuhan lingkungan dan kebutuhan anak dengan sistematika penyusunan program terdiri dari perumusan rasional, visi dan misi, pengertian, deskripsi kebutuhan, perumusa tujuan, rencana operasional (action plan), pengembangan tema atau topik, perumusan program, pengembangan satuan layanan, rencana evaluasi dan rencana anggaran.

\section{DAFTAR PUSTAKA}

Asrori. 2008. Perkembangan Peserta Didik. Pontianak: Untan Press

Blocher, D. H. 1974.Developmental Counseling. New York: Santa Barbara

Buldani, D. 2010. "Bimbingan Guru dalam Mengoptimalkan Perkembangan Kognitif Anak Usia Dini di TK Sekecamatan Jatinangor Kabupaten Sumedang”. Tesis.Bandung: Program Pascasarjana UPI.

Bunu, Y. H. 2012. "Masalah Anak Taman Kanak-Kanak Menurut Guru dan Orangtua serta Implementasiya dalam Bimbingan Dan Konseling" JurnalBimbingan dan Konseling Unnes, Volume 1 No. 2.

Cicchetti, D. dan Cohen, D. J. 2006.Developmental Psychopathology: Theory and Method. Canada: Wiley

Departemen Pendidikan Nasional. 2009. Peraturan Menteri Pendidikan Nasional Nomor 58 Tahun 2009 tentang Standar Pendidikan Anak Usia Dini. Jakarta 
Dyatmika, M. W. 2009.“Implementasi Prinsip-prinsip Bimbingan dan Konseling di Raudhatul Athfal (RA) Nururrahman Bandung”.Tesis. Bandung: Program Pascasarjana UPI

Friedman, H. J. dan Schustack, M. W. 2008. Kepribadian, Teori Klasik dan Modern, Jakarta: Erlangga

Gottman dan DeClaire. 2008. Mengembangkan Kecerdasan Emosi Anak. Jakarta: PT Gramedia

Hurlock, E. B. 1980. Psikologi Perkembangan. Jakarta: Erlangga

Izzaty, I. R. 2012."Illustrated Story Books as a Instrument for Developing Teacher's Skills in Counseling with Kindergarten Children with Self-Adjustment Difficulties"Seminar Internasional Bimbingan dan Konseling di Yogyakarta, 8 sampai 9 September

Kurnia, A. (2005). Program Bimbingan untuk Mencapai Tugas Perkembangan di Taman Kanak-kanak (TK) Bumi Silliwangi UPI, Aisyiyah 10 dan Pembina Sadang Serang Bandung. Tesis. Bandung: Program Pascasarjana UPI

Muro, J. J. dan Kottman, T. 1995. Guidance and Counseling in The Elementaty and Middle Schools. University of North Texas : Brown Communications, inc

Myrick, R. D. 2011. Developmental Guidance and Counseling: A Practical Approach. United States of America: Educational Media Corporation

Nurihsan, A. J. dan Agustin, M. 2011. Dinamika Perkembangan Anak dan Remaja. Bandung: Rafika Aditama

Prayitno \& Amti, E. 1999.Dasar-dasar Bimbingan dan Konseling. Jakarta: Reneka Cipta

Putra, N. \& Dwilestari, N. 2012.Penelitian Kualitatif Pendidikan Anak Usia Dini (PAUD). Jakarta: Raja Grafindo Persada

Rahman, F. 2006. Konseling Tiga Dimensi; Ide dan Praktik Ekologi Perkembangan dalam Memahami Problem Klien dan Komunitas, Seminar Bimbingan dan Konseling di Yogyakarta, 15 September 2006

Salahudin, A. 2010.Bimbingan dan Konseling, Bandung: CV Pustaka Setia

Samsudi. 2009. Disain Penelitian Pendidikan. Semarang: UNNES Pres

Setiadi, E. 2004.Pengembangan Program Bimbingan dan Konseling dalam Sistem Pendidikan Prasekolah di TK Salman Al-Farisi Bandung, Tesis. Bandung: Program Pascasarjana UPI

Sobur. 2005. Psikologi Umum. Bandung: Pustaka Setia

Soetjiningsih, J. H. 2012. Perkembangan Anak: Sejak Pembuahan Sampai Kanak-Kanak Akhir. Jakarta: Kencana

Subana dan Sudrajat. 2005.Statistik Penelitian. Bandung : Pustaka Setia

Sugiyono. 2011b. Metode Penelitian Administrasi. Bandung: Alfabeta

Susanto, A. 2011. Perkembangan Anak Usia Dini. Jakarta: Kencana 
Suyadi. 2010. Bimbingan Konseling untuk Pendidikan Anak Usia Dini (PAUD). Yogyakarta: DIVA Press

Syaodih, E. 2005.Bimbingan di Taman Kanak-Kanak. Jakarta: Depdiknas Direktorat Jendral PendidikanTinggi

Wibowo, M.E. 2005. Konseling Kelompok Perkembangan. Semarang: UNNES Press

Winkel, W. S. dan Hastuti, S. 2012. Bimbingan dan Konseling di Institusi Pendidikan. Yogyakarta: Media Abadi

Yusuf, S. 2001a. Psikologi Perkembangan Anak dan Remaja. Bandung: PT Remaja Rosdakarya

2009b. Program Bimbingan dan Konseling di Sekolah. Bandung: RIZQI Press 